\title{
Corynebacterium diphtheriae putative tellurite-resistance protein (CDCE8392_0813) contributes to the intracellular survival in human epithelial cells and lethality of Caenorhabditis elegans
}

\author{
Louisy Sanches dos Santos' ${ }^{1}$ Camila Azevedo Antunes², Cintia Silva dos Santos ${ }^{1}$, \\ José Augusto Adler Pereira', Priscila Soares Sabbadini ${ }^{3}$, Maria das Graças de Luna', \\ Vasco Azevedo ${ }^{2}$, Raphael Hirata Júnior ${ }^{1}$, Andreas Burkovski ${ }^{4}$, \\ Lídia Maria Buarque de Oliveira Asad ${ }^{5}$, Ana Luíza Mattos-Guaraldi++
}

\begin{abstract}
${ }^{1}$ Universidade do Estado do Rio de Janeiro, Faculdade de Ciências Médicas, Departamento de Microbiologia, Imunologia e Parasitologia, Rio de Janeiro, RJ, Brasil ²Universidade Federal de Minas Gerais, Instituto de Ciências Biológicas, Departamento de Biologia Geral, Belo Horizonte, MG, Brasil ${ }^{3}$ Centro Universitário do Maranhão, Centro de Ciências da Saúde, Laboratório de Doenças Bacterianas, São Luís, MA, Brasil ${ }^{4}$ Friedrich-Alexander-Universität Erlangen-Nürnberg, Lehrstuhl fuer Mikrobiologie, Erlangen, Germany ${ }^{5}$ Universidade do Estado do Rio de Janeiro, Instituto de Biologia Roberto Alcântara Gomes,

Departamento de Biofísica e Biometria, Rio de Janeiro, RJ, Brasil
\end{abstract}

Corynebacterium diphtheriae, the aetiologic agent of diphtheria, also represents a global medical challenge because of the existence of invasive strains as causative agents of systemic infections. Although tellurite ( $\mathrm{TeO}_{3}^{2-}$ ) is toxic to most microorganisms, $\mathrm{TeO}_{3}^{2-}$-resistant bacteria, including $\mathrm{C}$. diphtheriae, exist in nature. The presence of $\mathrm{TeO}_{3}^{2-}-$ resistance $\left(T e^{R}\right)$ determinants in pathogenic bacteria might provide selective advantages in the natural environment. In the present study, we investigated the role of the putative Te $e^{R}$ determinant (CDCE8392_813 gene) in the virulence attributes of diphtheria bacilli. The disruption of CDCE8392_0813 gene expression in the LDCIC-L1 mutant increased susceptibility to $\mathrm{TeO}_{3}^{2-}$ and reactive oxygen species (hydrogen peroxide), but not to other antimicrobial agents. The LDCIC-L1 mutant also showed a decrease in both the lethality of Caenorhabditis elegans and the survival inside of human epithelial cells compared to wild-type strain. Conversely, the haemagglutinating activity and adherence to and formation of biofilms on different abiotic surfaces were not regulated through the CDCE8392_0813 gene. In conclusion, the CDCE8392_813 gene contributes to the Te $e^{R}$ and pathogenic potential of C. diphtheriae.

Key words: Corynebacterium diphtheriae - tellurite-resistance - CDCE8392_0813 protein - HEp-2 cells - Caenorhabditis elegans

Tellurium (Te) is a metalloid that exists as a trace component in natural environments. Te compounds are used in industrial processes and increased delivery of these compounds into the environment generates pollution in soil and water, potentially resulting in contamination and subsequent adverse effects on public health (Avazéri et al. 1997, Aradská et al. 2013). Tellurite $\left(\mathrm{TeO}_{3}{ }^{2-}\right)$, one of the most oxidised and soluble forms of Te, is toxic to both prokaryotes and eukaryotes. Among prokaryotes, Gram-negative bacteria are particularly susceptible to Te salts, whereas some Gram-positive bacteria are naturally resistant. Te compounds have a long history as antimicrobial and therapeutic agents for the treatment of infectious diseases, e.g., hanseniasis and tuberculosis.

doi: 10.1590/0074-02760140479

Financial support: CAPES, FAPERJ, CNPq, UERJ (SR-2/UERJ),

PNPD-CAPES/MEC, PAPD-FAPERJ/CAPES

LSS and CAA contributed equally to this work.

+ Corresponding author: guaraldi@uerj.br

Received 17 December 2014

Accepted 15 May 2015
Although Te compounds have not been overlooked as antimicrobial agents, recent investigations studies concerning their biochemical properties and toxicity mechanisms of these molecules have identified Te compounds as potential candidates for use as antibiotics, anticancer drugs and therapeutic agents for the treatment of Parkinson's disease (Ba et al. 2010, Sekhon 2013). Currently, $\mathrm{TeO}_{3}^{2-}$ is used as a selective agent in the culture media of some pathogens, such as Corynebacterium diphtheriae and Staphylococcus aureus (Taylor 1999).

Although little is known about the mechanisms of $\mathrm{TeO}_{3}^{2-}$-resistance $\left(\mathrm{Te}^{\mathrm{R}}\right)$, numerous plasmid and/or chromosomally encoded $\mathrm{Te}^{\mathrm{R}}$ determinants have been identified in different bacterial species, including human pathogens. The presence of $\mathrm{Te}^{\mathrm{R}}$ determinants in pathogenic bacteria suggests that these genes might provide some selective advantage in the environment and might also be associated with pathogenicity (Pei et al. 2013, Franks et al. 2014). Previous studies have demonstrated that these determinants are involved in resistance to bacteriophages and colicins (Whelan et al. 1995), antiseptics and disinfectants (Teitzel \& Parsek 2003) and antimicrobials (Collins et al. 2010, Pei et al. 2013, Franks et al. 2014). In addition, these genes have also been implicated in adherence to epithelial cells (Yin et al. 2009, Pei et al. 2013) and susceptibility to reactive oxygen species (ROS) (Franks et al. 2014). 
Currently, various virulence factors of $C$. diphtheriae have been described, including the production of potent exotoxin, the formation of biofilms (Gomes et al. 2009), adherence, invasion and survival within different types of human cells (Hirata Jr et al. 2002, Bertuccini et al. 2004, Santos et al. 2010, Peixoto et al. 2014). The major aetiologic agent of diphtheria is also one of the most well-known $\mathrm{Te}^{\mathrm{R}}$ pathogens. However, the mechanisms involved in this resistance and its relevance in the pathogenicity of $C$. diphtheriae remain unknown. Therefore, in the present study, we detected a putative $\mathrm{Te}^{\mathrm{R}}$ determinant in $C$. diphtheriae strain CDC-E8392 (CDCE8392_0813 protein) and showed a role for this gene in C. diphtheriae infection, analysing its effects on resistance to antimicrobial agents and hydrogen peroxide $\left(\mathrm{H}_{2} \mathrm{O}_{2}\right)$, adherence to biotic and abiotic surfaces, intracellular survival and ability to kill nematodes.

\section{MATERIALS AND METHODS}

Bacterial strains and growth conditions - C. diphtheriae strains used in this study and their characteristics are listed in Table I. These microorganisms were maintained in trypticase soy broth (TSB) (BD Difco ${ }^{\mathrm{TM}}$, USA) at $37^{\circ} \mathrm{C}$ and stored in the same medium with $20 \%$ glycerol. Escherichia coli TOP10 Electrocomp ${ }^{\mathrm{TM}}$ (Thermo Fisher Scientific Inc Invitrogen ${ }^{\mathrm{TM}}$, USA) and E. coli OP50 were grown in Luria Bertani (BD Difco ${ }^{\mathrm{TM}}$ ) medium at $37^{\circ} \mathrm{C}$. When appropriate, kanamycin (Sigma-Aldrich Co, USA) was added $\left(50 \mu \mathrm{g} \mathrm{mL}^{-1}\right)$.

In silico search and three-dimensional model prediction of the putative Te $e^{R}$ protein - An in silico search for resistance determinants in $C$. diphtheriae strains was conducted through the Protein Bank of the National Center for Biotechnology Information. A hypothetical protein included in the $\mathrm{TeO}_{3}^{2-}$ resistance/dicarboxylate transporter family was identified in all sequenced strains.

The Phyre2 server was used to predict the three-dimensional structure of the putative $\mathrm{Te}^{\mathrm{R}}$ protein of $C$. diphtheriae (Kelley \& Sternberg 2009, Guo et al. 2012, Torktaz et al. 2012, Nema \& Pal 2013). Two parameters were considered to select the best model: confidence and coverage.

Disruption of the putative Te $e^{R}$ gene - For the chromosomal disruption of the $C$. diphtheriae putative $\mathrm{Te}^{\mathrm{R}}$ gene, the TOPO ${ }^{\circledR}$ TA Cloning ${ }^{\circledR}$ Kit (Thermo Fisher Scientific Inc Invitrogen ${ }^{\mathrm{TM}}$ ) was used. The CDC-E8392 strain was chosen as template and a $207 \mathrm{bp}$ internal DNA fragment from CDCE8392_0813 gene was amplified via polymerase chain reaction (PCR) with the following primer pair: 5'-TCGTTTTATGCGGGTGC-3' and 5'-GGTGTGCGCAATCTGATG-3'. Amplification was performed with an initial denaturation step at $94^{\circ} \mathrm{C}$ for $2 \mathrm{~min}$, followed by 35 cycles of denaturation at $94^{\circ} \mathrm{C}$ for $1 \mathrm{~min}$, annealing at $60^{\circ} \mathrm{C}$ for $1 \mathrm{~min}$ and extension at $72^{\circ} \mathrm{C}$ for $1 \mathrm{~min}$ and $30 \mathrm{~s}$ and a final elongation step at $72^{\circ} \mathrm{C}$ for $10 \mathrm{~min}$.

The DNA fragment was ligated to the overhanging 3'deoxythymidine of linearised pCR2.1-TOPO vector provided in the kit. The resulting plasmid "pCR2.1-TOPOCDCE8392_0813" was propagated in E. coli TOP10 Electrocomp ${ }^{\mathrm{TM}}$ according to the manufacturer's instructions and isolated using the PureLink Quick DNA Miniprep Kit (Thermo Fisher Scientific Inc Invitrogen ${ }^{\mathrm{TM}}$ ). Five

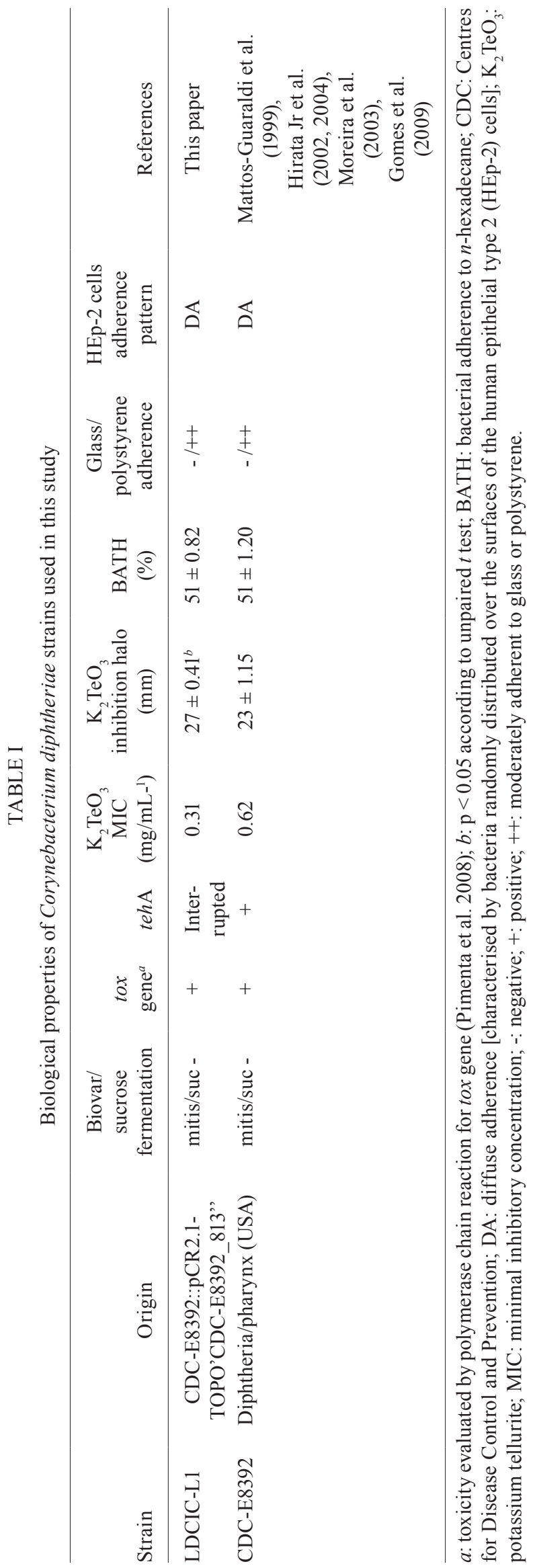


micrograms of unmethylated plasmid isolated from this E. coli strain was used to transform $C$. diphtheriae using a GenePulser II (Bio-Rad Laboratories Inc, USA), as previously described (Dorella et al. 2006). The electroporated cells were added to $1 \mathrm{~mL}$ of TSB and incubated for $4 \mathrm{~h}$ at $37^{\circ} \mathrm{C}$. The culture was plated onto a TSB agar plate containing kanamycin and maintained at $37^{\circ} \mathrm{C}$ for $48 \mathrm{~h}$. Because pCR2.1-TOPO cannot autonomously replicate in $C$. diphtheriae, kanamycin-resistant $C$. diphtheriae carried the vector, integrated via recombination into the chromosomal CDCE8392_0813 gene and designated LDCIC-L1.

To confirm the insertion of the plasmid into the chromosome of the $C$. diphtheriae strain CDC-E8392, PCR reactions using primers aligned at the start and stop codons of the CDCE8392 0813 gene (5'-TCGTATCAATGCGTGCCACAG-3' and 5'-AATCGTGCGCTGCCATACATG-3') and primers aligned within the inserted plasmid [Kan\#1 5'-ATGATTGAACAAGATGGATTG-3' Kan\#2 5'-TTAATAATTCAGAAGAACTC-3' and M13F/ M13R (Life Technologies)] were performed as previously described (Dorella et al. 2006, Pacheco et al. 2012).

$\mathrm{TeO}_{3}^{2-}$ susceptibility assays - Potassium tellurite $\left(\mathrm{K}_{2} \mathrm{TeO}_{3}\right)$ sensitivity was evaluated through determination of the minimal inhibitory concentration (MIC) by using the disk diffusion method according to the protocols of the Clinical Laboratory Standards Institute (CLSI) for antimicrobials (CLSI 2013). The $\mathrm{MIC}$ of $\mathrm{K}_{2} \mathrm{TeO}_{3}$ was determined using bacterial cells grown for $48^{2} \mathrm{~h}$ at $37^{\circ} \mathrm{C}$ in trypticase soy agar (BD Difco ${ }^{\mathrm{TM}}$ ) suspended in Müller Hinton broth (BD Difco ${ }^{\mathrm{TM}}$ ) to a final concentration of $10^{8}$ colony forming units (CFU) $\mathrm{mL}^{-1}$ and diluted 1,000-fold into medium supplemented with various concentrations of $\mathrm{K}_{2} \mathrm{TeO}_{3}$ (Sigma-Aldrich Co) ranging from $0.0-2.5 \mathrm{mg} /$ $\mathrm{mL}^{-1}$. After incubation for $48 \mathrm{~h}$ at $37^{\circ} \mathrm{C}$, the growth was visually assessed. The disk diffusion assay was performed with $10^{8} \mathrm{CFU} \mathrm{mL} \mathrm{mL}^{-1}$ bacteria spread onto cation-adjusted Müller-Hinton agar plates (BD Difco ${ }^{\mathrm{TM}}$ ). The disks were then impregnated with $1 \mathrm{M}$ of $_{2} \mathrm{TeO}_{3}$. After $48 \mathrm{~h}$ at $37^{\circ} \mathrm{C}$, the diameters of the zones were determined.

Antimicrobial susceptibility testing - The sensitivity to antimicrobial agents (Oxoid Ltd, UK), penicillin (10 $\mu \mathrm{g})$, erythromycin $(15 \mu \mathrm{g})$, ampicillin $(10 \mu \mathrm{g})$, gentamicin $(10 \mu \mathrm{g})$, cefotaxime $(30 \mu \mathrm{g})$, imipenem $(10 \mu \mathrm{g})$, ciprofloxacin $(5 \mu \mathrm{g})$, clindamycin $(2 \mu \mathrm{g})$, rifampicin $(30 \mu \mathrm{g})$, tetracycline $(30 \mu \mathrm{g})$, linezolid $(30 \mu \mathrm{g})$ and vancomycin $(5 \mu \mathrm{g})$, was determined using the disk diffusion method according to CLSI (2013) guidelines, as previously described (Pereira et al. 2008). The inoculum equivalent to a $0.5 \mathrm{McF}$ arland standard was placed on the surface of a cation-adjusted Müller-Hinton agar containing 5\% sheep blood. The plates were subsequently incubated at $37^{\circ} \mathrm{C}$ for $24 \mathrm{~h}$ and reconfirmed at $48 \mathrm{~h}$. Breakpoints for the susceptible strains were used in accordance with the CLSI for bacteria excluded from table 2A-J. Because there is no defined standard for interpreting these results, the results were interpreted in accordance with (CLSI 2010). The breakpoints for $S$. aureus, established by CLSI, were considered in the cases of penicillin.

Agar diffusion growth inhibition assays for susceptibility to $\mathrm{H}_{2} \mathrm{O}_{2}$ - The sensitivity to $\mathrm{H}_{2} \mathrm{O}_{2}$ was assessed based on the methods of Kim and Holmes (2012) with some adaptations. Approximately $10^{8} \mathrm{CFU} \mathrm{mL} \mathrm{mL}^{-1}$ were spread onto the surface of cation-adjusted Müller-Hinton agar plates. A $10-\mu \mathrm{L}$ aliquot of $20 \mathrm{mM} \mathrm{H}_{2} \mathrm{O}_{2}$ was spotted onto the centre of the plate and the diameter of the growth inhibition zone was measured after an incubation period of 24-48 h.

Nematode infection model - The assays were performed as previously described with some adaptations (Browning et al. 2013). Briefly, Caenorhabditis elegans $\mathrm{N} 2$ was maintained on plates containing nematode growth medium (NGM) agar for approximately six-seven days at $20^{\circ} \mathrm{C}$ and used in infection assays with wild-type (WT) and mutant (LDCIC-L1) C. diphtheriae strains. Twenty L4 stage larval worms were infected with $20 \mu \mathrm{L}$ of each bacterial strain (obtained from an overnight culture) on NGM plates at $20^{\circ} \mathrm{C}$ for $24 \mathrm{~h}$. The worms were assessed daily following infection and the dead nematodes were counted and removed every $24 \mathrm{~h}$ for seven days. For each strain, approximately 60 nematodes were used and the assays were performed three times. E. coli OP50 was used as a control in these experiments.

Biofilm formation on polystyrene surfaces - Biofilm formation was determined in 96 well flat-bottomed polystyrene microtitre plates based on previously described methods (Gomes et al. 2009). Briefly, $200 \mu \mathrm{L}$ of the bacterial suspension with an optical density (OD) of $0.2(\lambda$ $=570 \mathrm{~nm}$ ) in TSB medium was applied to each well of the microplate. For the negative control, only TSB was applied to the well. After an incubation period of $48 \mathrm{~h}$ at $37^{\circ} \mathrm{C}$, the content of each well was aspirated and washed with $0.01 \mathrm{M}$ phosphate-buffered saline (PBS) (pH 7.2). The remaining attached bacteria were fixed with $99 \%$ methanol and stained with $2 \% \mathrm{v} / \mathrm{v}$ crystal violet. The bound dye was subsequently solubilised using $33 \%$ glacial acetic acid and the OD of the solution was measured at $570 \mathrm{~nm}$ using an enzyme immunosorbent assay reader (BioRad Laboratories Inc; model 550). The cut-off OD (ODc) was defined as the mean OD of the negative control. The strains were classified into the following categories: nonadherent $\left(0: \mathrm{OD} \leq \mathrm{OD}_{\mathrm{c}}\right)$, weakly adherent $(+$ : $\mathrm{OD}_{\mathrm{c}}<\mathrm{OD} \leq 2 \mathrm{x}$ OD $)$, moderately adherent $\left(++: 2 \mathrm{x} \mathrm{OD}_{\mathrm{c}}<\right.$ $\mathrm{OD}^{\mathrm{c}} \leq 4 \mathrm{x} \mathrm{OD}_{\mathrm{c}}$ ) or strongly adherent (+++: $\left.4 \mathrm{x}_{\mathrm{c}} \leq \mathrm{OD}\right)$.

Bacterial adherence to $n$-hexadecane (BATH) assays - The evaluation of bacterial adhesion to $n$-hexadecane was performed as previously described (Mattos-Guaraldi et al. 1999). Strains with BATH values $>50 \%$ were considered highly hydrophobic, $30 \% \leq$ BATH values $<50 \%$ were considered moderately hydrophobic and BATH values $<30 \%$ were considered hydrophilic.

Biofilm formation on glass surfaces and haemagglutination assays - The haemagglutination activity of human $\mathrm{B}$ erythrocytes $(0.5 \%)$ and bacterial adhesion to glass surfaces were both assayed using previously described methods (Mattos-Guaraldi \& Formiga 1991). The microorganisms were classified into the following categories for their ability to adhere onto glass: +++ (strong), confluent coat of cells on the sides of the tube and localised adherence (LA) onto the glass surface where the culture 


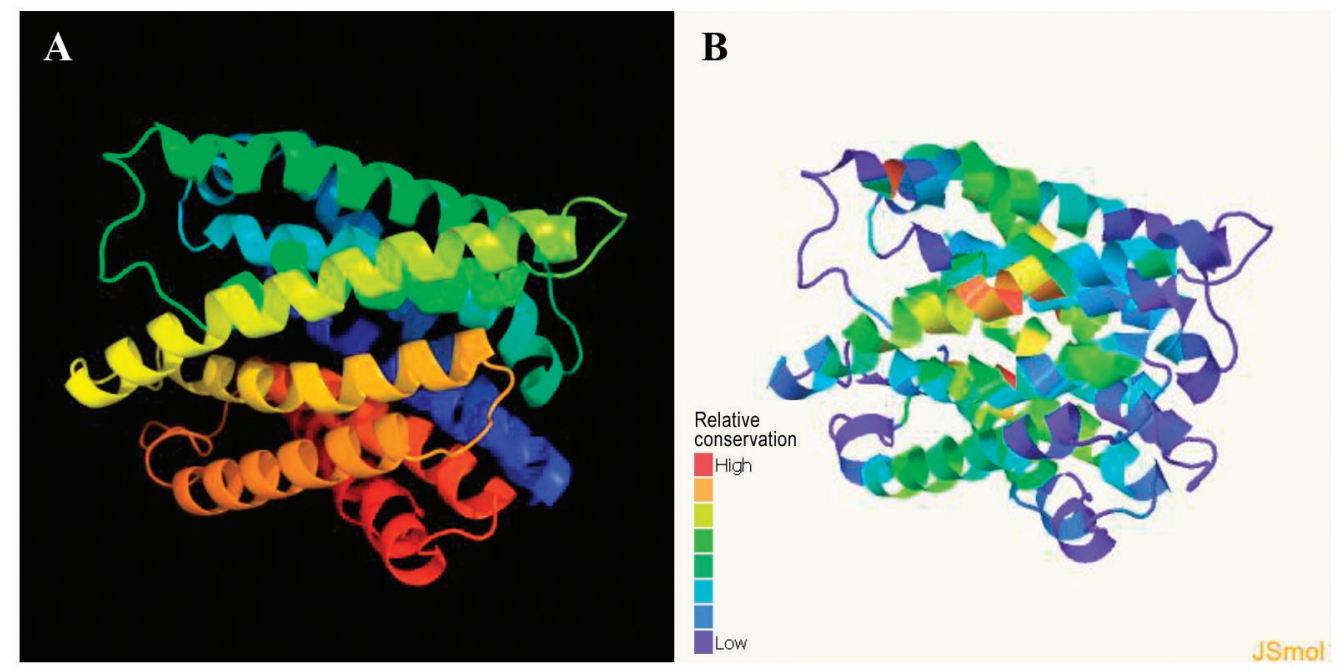

Fig. 1: three-dimensional models provided by Phyre2 server. A: best model for the CDCE 8392 _0813 protein ( $100 \%$ confidence and $84 \%$ coverage); B: conserved regions of CDCE8392_0813 protein.

medium is in contact with the air, ++ (intermediate), confluent coat of cells on the sides of the tube, + (weak), LA onto the glass surface where the culture medium is in contact with air, and - (negative), no visible adherence.

Human epithelial type 2 (HEp-2) cell interaction assays - The cellular interaction assays were performed using epithelial cells derived from a human epidermoid larynx carcinoma (HEp-2) according to previously described protocols (Hirata Jr et al. 2002, 2004, 2008). Briefly, microorganisms grown in TSB were used to infect monolayers of HEp-2 cells grown to approximately $95 \%$ confluence. After $3 \mathrm{~h}$ of interaction, the infected monolayers were washed with 0.01 M PBS (pH 7.2), lysed with $0.1 \%$ Triton X-100 (Sigma-Aldrich Co) in PBS, diluted and plated. Viable bacterial counts in the supernatant and cellular monolayer lysates were subsequently determined. To determine the viable intracellular bacteria, the monolayers were treated with $150 \mu \mathrm{g} \mathrm{mL}^{-1}$ of penicillin (Sigma-Aldrich Co) for $1 \mathrm{~h}$. The adherence pattern assays were performed using semi-confluent HEp-2 monolayers grown on circular coverslips (13 $\mathrm{mm}$ diameter). At 3 $\mathrm{h}$ post-infection, the Giemsa-stained coverslips were examined using bright field microscopy and the observed strains were classified into the following patterns: LA, characterised by small clusters of bacteria resembling micro-colonies, diffuse adherence (DA), characterised by bacteria randomly distributed over the surfaces of the HEp-2 cells, or aggregative adherence characterised by clumps of bacteria with a "stacked-brick" appearance.

Statistical analysis - Each experiment was conducted in triplicate and statistical analyses were performed with the appropriate tests using a GraphPad Prism 5.0 (GraphPad, USA). $\mathrm{p}<0.05$ was considered significant.

\section{RESULTS}

CDCE8392_0813 protein represented a Te $\mathrm{T}^{R}$ protein TehA homolog - The structure and function of the putative $\mathrm{Te}^{\mathrm{R}}$ protein in C. diphtheriae CDC-E8392
(CDCE8392 0813 protein) were predicted using a protein homology/analogy recognition engine (Phyre). The best model selected by the Phyre2 server is displayed in Fig. 1A. The 302-residue protein was modelled with $100 \%$ confidence and $84 \%$ coverage (302 residues of the sequence). According to analyses of this protein, the sequence represented a $\mathrm{Te}^{\mathrm{R}}$ protein $\mathrm{TehA}$ homolog. The highest conserved region, shown in red in Fig. 1B, is likely part of the active protein site.

CDCE8392_0813 interruption rendered the mutants more susceptible to $\mathrm{K}_{2} \mathrm{TeO}_{3}$ and $\mathrm{H}_{2} \mathrm{O}_{2}$ toxicity, but did not modify antimicrobial susceptibility profiles - The $\mathrm{Te}^{\mathrm{R}}$ resistance level of the mutant LDCIC-L1 (CDCE8392::pCR2.1-TOPO'CDC-E8392_813'”), constructed via homologous recombination, was determined and compared with that of the WT strain (CDC-E8392). An increase $(2 \mathrm{x})$ in the susceptibility to $\mathrm{TeO}_{3}{ }^{2-}$ was observed for the mutant $\left(\mathrm{MIC}=0.3125 \mathrm{mg} / \mathrm{mL}^{-1}\right)$. Furthermore, in disk diffusion assays, LDCIC-L1 presented a $27.00 \mathrm{~mm}$ $( \pm 0.41)$ growth inhibition zone, which was significantly different $(p=0.0006)$ from the $23 \mathrm{~mm}( \pm 1.15)$ diameter inhibition zone of the WT strain. A significant difference was also observed for the sensitivity to $\mathrm{H}_{2} \mathrm{O}_{2}(\mathrm{p}=$ $0.0019)$. The WT strain presented a $22.00 \mathrm{~mm}( \pm 0.82)$ growth inhibition zone, while the mutant presented a $24.70 \mathrm{~mm}( \pm 0.64)$ inhibition zone (Table II).

Antimicrobial susceptibility assays demonstrated identical profiles for $C$. diphtheriae WT CDC-E8392 and LDCIC-L1 mutant strains. Both strains were determined to be susceptible to penicillin, erythromycin, ampicillin, gentamicin, cefotaxime, imipenem, ciprofloxacin, clindamycin, rifampicin, tetracycline, linezolid and vancomycin.

CDCE8392_0813 interruption affected the ability of C. diphtheriae to kill C. elegans and survive within HEp cells - The results of the experiments using the nematode C. elegans revealed that the mutant strain LDCIC-L1 exhibited an attenuated killing ability when compared with the WT C. diphtheriae strain CDC-E8392 (Fig. 2). The 
TABLE II

Effects of Corynebacterium diphtheriae CDCE8392_0813 gene interruption on human cells interactions and on susceptibility to hydrogen peroxide

\begin{tabular}{|c|c|c|c|c|c|c|}
\hline \multirow[b]{2}{*}{ Strain } & \multirow[b]{2}{*}{$\begin{array}{l}\text { HA } \\
\text { titre }\end{array}$} & \multicolumn{4}{|c|}{ Human epithelial type 2 epithelial cell } & \multirow[b]{2}{*}{$\begin{array}{c}\mathrm{H}_{2} \mathrm{O}_{2} \\
\text { inhibition halo } \\
(\mathrm{mm})\end{array}$} \\
\hline & & $\begin{array}{c}\text { Adherence } \\
\text { pattern }\end{array}$ & $\begin{array}{c}\text { Bacteria } \\
\text { in supernatant } \\
\left(\mathrm{CFU} \mathrm{mL} \mathrm{mL}^{1-}\right)\end{array}$ & $\begin{array}{c}\text { Adherent } \\
\text { bacteria } \\
\left(\mathrm{CFU} \mathrm{mL} \mathrm{mL}^{1-}\right)\end{array}$ & $\begin{array}{l}\text { Internalised } \\
\text { bacteria } \\
\left(\mathrm{CFU} \mathrm{mL} \mathrm{mL}^{1-}\right)\end{array}$ & \\
\hline LDCIC-L1 & 32 & DA & $11.8 \times 10^{4} \pm 2.23$ & $5.8 \times 10^{4} \pm 1.94$ & $7.0 \times 10^{2} \pm 0.05^{a}$ & $24.75 \pm 0.64^{a}$ \\
\hline CDC-E8392 & 32 & DA & $11.3 \times 10^{4} \pm 1.11$ & $5.3 \times 10^{4} \pm 1.30$ & $10.0 \times 10^{2} \pm 0.57$ & $22.00 \pm 0.82$ \\
\hline
\end{tabular}

$a: \mathrm{p}<0.05$ according to unpaired $t$ test; CFU: colony forming units; DA: diffuse adherence; HA: agglutination of human erythrocytes (type B).

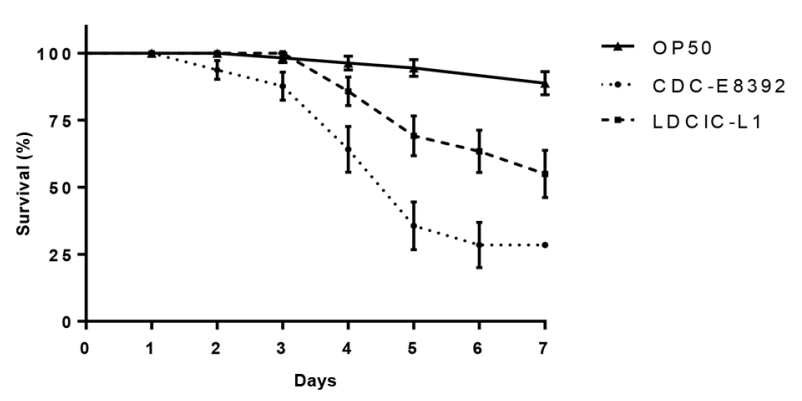

Fig. 2: Caenorhabditis elegans slow killing assays on nematode growth medium agar. The Kaplan-Meier statistical test was used to determine the probability of nematode survival. Survival curves were compared using the log rank test and considered statistically different $(\mathrm{p}<0.05)$.

data shown in Table II also indicated a reduced ability of the mutant to survive in the intracytoplasmic compartment of HEp-2 cells ( $\mathrm{p}=0.0391$ according to $t$ test). Strains CDC-E8392 and LDCIC-L1 reached internalisation rates of $1.89 \pm 0.15 \%$ and $1.21 \pm 0.35 \%$, respectively.

CDCE8392_0813 interruption did not affect the hydrophobicity and adherence properties of C. diphtheriae - The ability of $C$. diphtheriae LDCIC-L1 to adhere to and to form a biofilm on abiotic surfaces was evaluated using glass and polystyrene adherence assays. Simultaneously, the surface hydrophobicity of this strain was analysed through BATH assays and haemagglutinating activity. The mutant showed nonadherence to the glass and moderate adherence to polystyrene surfaces (Table I). The mutant also preferred a hydrophobic surface ( $\%$ BATH $=51)($ Table I $)$ and the displayed haemagglutinating activity (titre $=32$ ) (Table II).

The adherence of the mutant strain to HEp cells was verified using the HEp-2 lineage; the results are displayed in Table II. Similar to the WT strain, the mutant strain showed a DA pattern with a moderate degree of adherence $(31.9 \%)$ after $3 \mathrm{~h}$ of interaction. The adherence values were not considered to be significantly different from the parental strain according to unpaired $t$ test $(\mathrm{p}>0.01)$.

\section{DISCUSSION}

A number of genetic $\mathrm{Te}^{\mathrm{R}}$ determinants have been identified in different bacterial species (Taylor et al. 1994, Liu \& Taylor 1999, Toptchieva et al. 2003). One of the chromosomal $\mathrm{Te}^{\mathrm{R}}$ determinants is the operon teh $\mathrm{AB}$, originally described in E. coli. Homologues and orthologues of the teh $\mathrm{A}$ gene have been identified in other bacterial species, such as Vibrio cholerae, Klebsiella pneumoniae, Salmonella enterica and Corynebacterium glutamicum (Chasteen et al. 2009, Pei et al. 2013). Recent studies have revealed that this determinant did not confer the $\mathrm{Te}^{\mathrm{R}}$ mechanism of $V$. cholerae C6706, but was found involved in antibiotic resistance and intestinal colonisation (Pei et al. 2013).

For $C$. diphtheriae, a protein with similar sequence to TehA in other species was identified. This protein, referred to as CDCE8392_0813 in CDC-E8392 strain, was predicted as a $\mathrm{Te}^{\mathrm{R}}$ protein $\mathrm{Teh} A$ homologue using Phyre software. In the present study, the contribution of $\mathrm{Te}^{\mathrm{R}}$ to $C$. diphtheriae pathogenesis was verified using the CDCE8392_0813 mutant (LDCIC-L1) constructed through chromosomal disruption. According to Phyre, the interrupted region of the CDCE8392_0813 gene likely corresponded to the protein active site because it contained many conserved residues. Gene complementation was not performed in the present study and might be considered to be a limitation of this work.

The influence of the CDCE8392_0813 protein in the $\mathrm{Te}^{\mathrm{R}}$ mechanism of strain CDC-E8392 was also documented in the present study. Two different protocols used to investigate the viability of LDCIC-L1 in the presence of $\mathrm{TeO}_{3}^{2-}$ revealed that this gene interruption rendered the mutant more susceptible to this compound. It has been previously suggested that $\mathrm{Te}^{\mathrm{R}}$ depends on the expression of different enzymes involved in several bacterial functions, including nitrate reduction, oxidative stress response and phosphate and cysteine metabolism (Taylor 1999, Chasteen et al. 2009, Franks et al. 2014). However, the data obtained in the present study suggest that CDCE8392_0813 participates in C. diphtheriae $\mathrm{Te}^{\mathrm{R}}$ and that this mechanism relies on other bacterial factors. The data also indicate that additional studies are needed to identify and characterise these other bacterial factors. 
A recent report indicated that TehA protein participates in $V$. cholerae antimicrobial resistance (Pei et al. 2013). In contrast, the findings presented here indicated that the TehA homologue is not involved in the susceptibility of $C$. diphtheriae to the antimicrobial agents tested.

It has previously been suggested that $\mathrm{TeO}_{3}^{2-}$ toxicity results, at least in part, from the generation of ROS including $\mathrm{H}_{2} \mathrm{O}_{2}$. However, $\mathrm{TeO}_{3}{ }^{2-}$ resistance is likely mediated via resistance to oxidative damage rather than the detoxification of the metal oxide itself (Toptchieva et al. 2003, Chasteen et al. 2009, Whitby et al. 2010). Due to this, the CDCE83912_0813 mutant was further examined to determine its resistance to $\mathrm{H}_{2} \mathrm{O}_{2}$. This mutant exhibited increased sensitivity to tellurite. Similar results were observed with a Haemophilus influenzae mutant for tehB (Whitby et al. 2010).

Because the participation of TehA in bacterial pathogenesis has been described for other species, we evaluated the involvement of the putative $\mathrm{Te}^{\mathrm{R}}$ determinant CDCE8392 0813 in the virulence of diphtheria bacilli. Using C. elegans as an infection model, we considered a simple but versatile animal model for analysing the virulence of bacteria, including $C$. diphtheriae (Broadway et al. 2013). Herein, we demonstrated an attenuated ability of the LDCIC-L1 mutant to kill nematodes. Similarly, mutations in the $\mathrm{Te}^{\mathrm{R}}$ genes of Bacillus anthracis (yce$G H$ ) also reduced survival in $C$. elegans and increased susceptibility to $\mathrm{TeO}_{3}{ }^{2-}$ compounds (Franks et al. 2014).

Despite the medical relevance of $C$. diphtheriae, only a few virulence factors have been characterised in detail. In addition to diphtheria toxin, adherence factors such as glycoconjugates, haemagglutinin and pili have been well studied. These factors might be involved in biofilm formation on abiotic surfaces and/or adherence to HEp cells and extracellular components (Mattos-Guaraldi et al. 2000, Colombo et al. 2001, Ott et al. 2010, Sabbadini et al. 2010, Antunes et al. 2015). Although these studies have demonstrated that a $\mathrm{Te}^{\mathrm{R}}$ determinant might assist $E$. coli $\mathrm{O} 157: \mathrm{H} 7$ in establishing an infection through participation in the adherence to eukaryotic cells (Yin et al. 2009), the data obtained in the present study showed that CDCE8392 0813 protein did not influence the adherence of $C$. diphtheriae to epithelial cells. Furthermore, these results revealed that CDCE8392_0813 did not act as an adhesin or modify the expression of bacterial factors involved in $C$. diphtheriae adhesion to abiotic surfaces.

The internalisation and intracellular survival of $C$. diphtheriae strains have been demonstrated for different human cells, including epithelial HEp-2 cells (Hirata Jr et al. 2002), Detroit 562 cell line (Bertuccini et al. 2004), human umbilical vein endothelial cells (Peixoto et al. 2014) and macrophage U937 cells (Santos et al. 2010). However, the mechanisms responsible for this property are not fully understood. These data showed that the intracellular survival of $C$. diphtheriae was reduced after the interruption of the CDCE8392 0813 gene. Because LDCIC-L1 showed increased $\mathrm{H}_{2} \mathrm{O}_{2}$ sensitivity, it is likely that this determinant also contributes to $C$. diphtheriae resistance to eukaryotic intracellular defences, such as the production of ROS, in addition to bacterial resistance to $\mathrm{TeO}_{3}^{2-}$ toxicity.
The CDCE8392_0813 gene interruption increased susceptibility to $\mathrm{Te}_{3}^{2-}$ toxicity, indicating that the putative $\mathrm{Te}^{\mathrm{R}}$ protein (CDCE8392_0813) (TehA) might act as the factor responsible for the expression of $\mathrm{Te}^{\mathrm{R}}$ in $C$. diphtheriae strains. Furthermore, $\mathrm{Te}^{\mathrm{R}}$ determinant might contributes to the pathogenesis of this species, as a direct correlation was verified between the expression of the CDCE8392 0813 gene and the abilities of $C$. diphtheriae to survive within the intracytoplasmic compartments of HEp cells and to kill the nematode C. elegans. Finally, the ability to kill the nematode $C$. elegans was verified.

\section{REFERENCES}

Antunes CA, dos Santos LS, Hacker E, Köhler S, Bösl K, Ott L, de Luna MG, Hirata Jr R, Azevedo VA, Mattos-Guaraldi AL, Burkovski A 2015. Characterization of DIP0733, a multi-functional virulence factor of Corynebacterium diphtheriae. Microbiology 161: 639-647.

Aradská J, Smidák R, Turkovičová L, Turňa J, Lubec G 2013. Proteomic differences between tellurite-sensitive and tellurite-resistant E.coli. PLoS ONE 11: e78010.

Avazéri C, Turner RJ, Pommier J, Weiner JH, Giordano G, Verméglio A 1997. Tellurite reductase activity of nitrate reductase is responsible for the basal resistance of Escherichia coli to tellurite. Microbiology 143: 1181-1189.

Ba LA, Döring M, Jamier V, Jacob C 2010. Tellurium: an element with great biological potency and potential. Org Biomol Chem 8: 4203-4216.

Bertuccini L, Baldassarri L, von Hunolstein C 2004. Internalization of non-toxigenic Corynebacterium diphtheriae by cultured human respiratory epithelial cells. Microb Pathog 37: 111-118.

Broadway MM, Rogers EA, Chang C, Huang IH, Dwivedi P, Yildirim S, Schmitt MP, Das A, Ton-That H 2013. Pilus gene pool variation and the virulence of Corynebacterium diphtheriae clinical isolates during infection of a nematode. J Bacteriol 195: 3774-3783.

Browning DF, Wells TJ, França FL, Morris FC, Sevastsyanovich YR, Bryant JA, Johnson MD, Lund PA, Cunningham AF, Hobman JL, May RC, Webber MA, Henderson IR 2013. Laboratory adapted Escherichia coli K-12 becomes a pathogen of Caenorhabditis elegans upon restoration of $\mathrm{O}$ antigen biosynthesis. Mol Microbiol 87: 939-950.

Chasteen TG, Fuentes DE, Tantaleán JC, Vásquez CC 2009. Tellurite: history, oxidative stress and molecular mechanisms of resistance. FEMS Microbiol Rev 33: 820-832.

CLSI - Clinical and Laboratory Standards Institute 2010. M45-A2. Methods for antimicrobial dilution and disk susceptibility testing of infrequently isolated or fastidious bacteria. Approved guideline, 2nd ed., CLSI, Wayne, 77 pp.

CLSI - Clinical and Laboratory Standards Institute 2013. M100-S-23. Performance for standards for antimicrobial susceptibility testing. Twenty-third informational supplement, CLSI, Wayne, 202 pp.

Collins B, Joyce S, Hill C, Cotter PD, Ross RP 2010. TelA contributes to the innate resistance of Listeria monocytogenes to nisin and other cell wall-acting antibiotics. Antimicrob Agents Chemother 54: 4658-4663.

Colombo AV, Hirata Jr R, Souza CM, Monteiro-Leal LH, Previato JO, Formiga LCD, Andrade AFB, Mattos-Guaraldi AL 2001. Corynebacterium diphtheriae surface proteins as adhesins to human erythrocytes. FEMS Microbiol Lett 197: 235-239.

Dorella FA, Estevam EM, Cardoso PG, Savassi BM, Oliveira SC, Azevedo V, Miyoshi A 2006. An improved protocol for electrotransformation of Corynebacterium pseudotuberculosis. Vet Microbiol 114: 298-303. 
Franks SE, Ebrahimi C, Hollands A, Okumura CY, Aroian RV, Nizet V, McGillivray SM 2014. Novel role for the yceGH tellurite resistance genes in the pathogenesis of Bacillus anthracis. Infect Immun 82: 1132-1140.

Gomes DL, Martins CA, Faria LM, Santos LS, Santos CS, Sabbadini PS, Souza MC, Alves GB, Rosa AC, Nagao PE, Pereira GA, Hirata Jr R, Mattos-Guaraldi AL 2009. Corynebacterium diphtheriae as an emerging pathogen in nephrostomy catheter-related infection: evaluation of traits associated with bacterial virulence. J Med Microbiol 58: 1419-1427.

Guo S, Garnham CP, Whitney JC, Graham LA, Davies PL 2012. Reevaluation of a bacterial antifreeze protein as an adhesin with ice-binding activity. PLOS ONE 7: e48805.

Hirata Jr R, Napoleão F, Monteiro-Leal LH, Andrade AFB, Nagao PE, Formiga LCD, Fonseca LS, Mattos-Guaraldi AL 2002. Intracellular viability of toxigenic Corynebacterium diphtheriae strains in HEp-2 cells. FEMS Microbiol Lett 215: 115-119.

Hirata Jr R, Pereira GA, Filardy AA, Gomes DL, Damasco PV, Rosa AC, Nagao PE, Pimenta FP, Mattos-Guaraldi AL 2008. Potential pathogenic role of aggregative-adhering Corynebacterium diphtheriae of different clonal groups in endocarditis. Braz J Med Biol Res 41: 986-991.

Hirata Jr R, Souza SM, Rocha-de-Souza CM, Andrade AFB, Monteiro-Leal LH, Formiga LCD, Mattos-Guaraldi AL 2004. Patterns of adherence to HEp-2 cells and actin polymerisation by toxigenic Corynebacterium diphtheriae strains. Microb Pathog 36: 125-130.

Kelley LA, Sternberg MJ 2009. Protein structure prediction on the Web: a case study using the Phyre server. Nat Protoc 4: 363-371.

Kim JS, Holmes RK 2012. Characterization of OxyR as a negative transcriptional regulator that represses catalase production in $\mathrm{Co}$ rynebacterium diphtheriae. PLoS ONE 7: e31709.

Liu M, Taylor DE 1999. Characterization of Gram-positive tellurite resistance encoded by the Streptococcus pneumoniae tehB gene. FEMS Microbiol Lett 174: 385-392.

Mattos-Guaraldi AL, Formiga LCD 1991. Relationship of biotype and source to the hemagglutination and adhesive properties of $\mathrm{Co}$ rynebacterium diphtheriae. Braz J Med Biol Res 24: 399-406.

Mattos-Guaraldi AL, Formiga LCD, Andrade AFB 1999. Cell surface hydrophobicity of sucrose-fermenting and non-sucrose-fermenting Corynebacterium diphtheriae strains evaluated by different methods. Curr Microbiol 38: 37-42.

Mattos-Guaraldi AL, Formiga LCD, Pereira GA 2000. Cell surface components and adhesion in Corynebacterium diphtheriae. Microbes Infect 2: 1507-1512.

Moreira LO, Andrade AF, Vale MD, Souza SM, Hirata Jr R, Asad LM, Asad NR, Monteiro-Leal LH, Previato JO, Mattos-Guaraldi AL 2003. Effects of iron limitation on adherence and cell surface carbohydrates of Corynebacterium diphtheriae strains. Appl Environ Microbiol 69: 5907-5913.

Nema V, Pal SK 2013. Exploration of freely available web-interfaces for comparative homology modelling of microbial proteins. Bioinformation 9: 796-801.

Ott L, Höller M, Rheinlaender J, Schäffer TE, Hensel M, Burkovski A 2010. Strain-specific differences in pili formation and the interaction of Corynebacterium diphtheriae with host cells. BMC Microbiol 10: 257.

Pacheco LG, Castro TL, Carvalho RD, Moraes PM, Dorella FA, Carvalho NB, Slade SE, Scrivens JH, Feelisch M, Meyer R, Miyoshi
A, Oliveira SC, Dowson CG, Azevedo V 2012. A role for sigma factor $\sigma(\mathrm{E})$ in Corynebacterium pseudotuberculosis resistance to nitric oxide/peroxide stress. Front Microbiol 3: 126.

Pei B, Wang Y, Katzianer DS, Wang H, Wu H, Zhong Z, Zhu J 2013. Role of a TehA homolog in Vibrio cholerae C6706 antibiotic resistance and intestinal colonization. Can J Microbiol 59: 136-139.

Peixoto RS, Pereira GA, dos Santos LS, Rocha-de-Souza CM, Gomes DL, Santos CS, Werneck LM, Dias AASO, Hirata Jr R, Nagao PE, Mattos-Guaraldi AL 2014. Invasion of endothelial cells and arthritogenic potential of endocarditis-associated Corynebacterium diphtheriae. Microbiology 160: 537-546.

Pereira GA, Pimenta FP, dos Santos FRW, Damasco PV, Hirata Jr R, Mattos-Guaraldi AL 2008. Antimicrobial resistance among Brazilian Corynebacterium diphtheriae strains. Mem Inst Oswaldo Cruz 103: 507-510.

Pimenta FP, Hirata Jr R, Rosa ACP, Milagres LG, Mattos-Guaraldi AL 2008. A multiplex PCR assay for simultaneous detection of Corynebacterium diphtheriae and differentiation between nontoxigenic and toxigenic isolates. J Med Microbiol 57: 1438-1439.

Sabbadini PS, Genovez MRN, da Silva CF, Adelino TLN, dos Santos CS, Pereira GA, Nagao PE, Dias AASO, Mattos-Guaraldi AL, Hirata Jr R 2010. Fibrinogen binds to nontoxigenic and toxigenic Corynebacterium diphtheriae strains. Mem Inst Oswaldo Cruz 105: 706-711.

Santos CS, Santos LS, Souza MC, Dourado FS, Dias AASO, Sabbadini PS, Pereira GA, Cabral MC, Hirata Jr R, Mattos-Guaraldi AL 2010. Non-opsonic phagocytosis of homologous non-toxigenic and toxigenic Corynebacterium diphtheriae strains by human U-937 macrophages. Microbiol Immunol 54: 1-10.

Sekhon BS 2013. Metalloid compounds as drugs. Res Pharm Sci 8: 145-158.

Taylor DE 1999. Bacterial tellurite resistance. Trends Microbiol 7: 111-115.

Taylor DE, Hou Y, Turner RJ, Weiner JH 1994. Location of a potassium tellurite resistance operon (tehAtehB) within the terminus of Escherichia coli K-12. J Bacteriol 176: 2740-2742.

Teitzel GM, Parsek MR 2003. Heavy metal resistance of biofilm and planktonic Pseudomonas aeruginosa. Appl Environ Microbiol 69: 2313-2320.

Toptchieva A, Sisson G, Bryden LJ, Taylor DE, Hoffman PS 2003. An inducible tellurite-resistance operon in Proteus mirabilis. Microbiology 149: 1285-1295.

Torktaz I, Etemadifar Z, Derikvand P 2012. Comparative modeling of $\mathrm{DszC}$, an enzyme in biodesulfurization and performing in silico point mutation for increasing tendency to oil. Bioinformation 8: $246-250$

Whelan KF, Colleran E, Taylor DE 1995. Phage inhibition, colicin resistance and tellurite resistance are encoded by a single cluster of genes on the IncHI2 plasmid R478. J Bacteriol 177: 5016-5027.

Whitby PW, Seale TW, Morton DJ, Van Wagoner TM, Stull TL 2010. Characterization of the Haemophilus influenzae teh $\mathrm{B}$ gene and its role in virulence. Microbiology 156: 1188-1200.

Yin X, Wheatcroft R, Chambers JR, Liu B, Zhu J, Gyles CL 2009. Contributions of $\mathrm{O}$ island 48 to adherence of enterohemorrhagic Escherichia coli $\mathrm{O} 157: \mathrm{H} 7$ to epithelial cells in vitro and in ligated pig ileal loops. Appl Environ Microbiol 75: 5779-5786. 